\title{
海難審判の裁決に関する抗告訴訟に付いて
}

\author{
木村 政文*・中川 丈久**・鈴木 三郎***・久保 雅義**
}

\section{Research on the Protest Suit Regarding of the Marine Accidents \\ Inquiry Agency Decision}

\author{
Masafumi KIMURA, Takehisa NAKAGAWA, \\ Saburou SUZUKI and Masayoshi KUBO
}

\begin{abstract}
The whaling vessel $6^{\text {th }}$ Seki Maru collided with the ferry boat Manjyu Maru near at south east offing Mutsure Shima, around 3:42p.m.,on September 21, 1949.

In this collision, the Hayashikane Shipbuilding Co., Ltd. did not receive a call in the Marine Court once, either, and oral proceedings was not opened, either and did not have presentation of evidence, either.

As for the cause of the collision, Japan Marine Accidents Inquiry Agency shall be based on the due to occupational cases negligence of the Shipbuilding Co., Ltd. concerned.

It canceled decision of Japan Marine Accidents Inquiry Agency that the Tokyo High Court had a reason in the protest suit of the above shipbuilding Co.,Ltd. concerned.

About decision of Japan Marine Accidents Inquiry Agency, the majority opinion of the Supreme Court judged that this was not what is only a fact check and affects the rights and duties of the shipbuilding Co., Ltd. and reversed judgment of Tokyo High Court.

Judgment of the Tokyo High Court is the same judgment as the minority opinion of the Supreme Court, and the large number theory of administration judicial precedent study group of those days is the same as judgment of the Tokyo High Court.

The Supreme Court has applied the Examinee's plaintiff qualification (except for reprimand decision). And new Article 9 the2nd clause of Administrative Case Litigation Law enforced from April 1, 2005 accepts plaintiff qualification widely. Therefore, although there is a problem, I think that it is necessary to interpret so that plaintiff qualification may be permitted to not only Examinee but also Designated Person Concerned in the Marine Accident.
\end{abstract}

Keywords : oral proceeding, judgement, decision, Marine Accident Inquiry

キーワード：口頭弁論、判決、裁決、海難審判

* 学生会員 神戸大学大学院自然科学研究科海事科学専攻（广658-0022 兵庫県神戸市東灘区深江南町 5-1-1）

** 正会員 神戸大学法学部法学研究科 （T657-8501 兵庫県神戸市灘区六甲台 1-1）

*** 名誉会員 神戸大学名誉教授 （テ651-1123 兵庫県神戸市北区ひよどり台 4-2-5）

** 正会員 神戸大学自然科学研究科 （广658-0022 兵庫県神戸市東灘区深江南町 5-1-1） 


\section{1. はじめに}

平成 17 年 4 月 1 日から施行された新行政事件訴訟 法(以下「行訴法」と略す)の 9 条 2 項で原告適格が拡 大されるようになった。海難審判における指定海難 関係人の原告適格の判断に、この行訴法第 9 条第 2 項の判断が拡大されるべきであると考え、指定海難 関係人の原告適格性を否定されてきた過去の海難事 件を考察することとした。

行政事件訴訟法第 9 条第 2 項 (抜粋)

・・・法律上の利益の有無を判断するに当たつ て、・・法令上の文言のみによることなく、当該 法令の趣旨及び目的並びに当該処分において考虑 されるべき利益の内容及び性質を考慮するものと する。

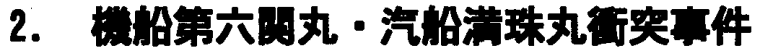

\section{1 衙突発生の日時、場所、天候}

昭和 24 年 9 月 21 日、午後 3 時 42 分頃、六連島南 東沖合で発生した。当時天候は最で東の南風が吹き、 現場付近は 1 時間 0.6 海里ばかりの南南西流があつ た。

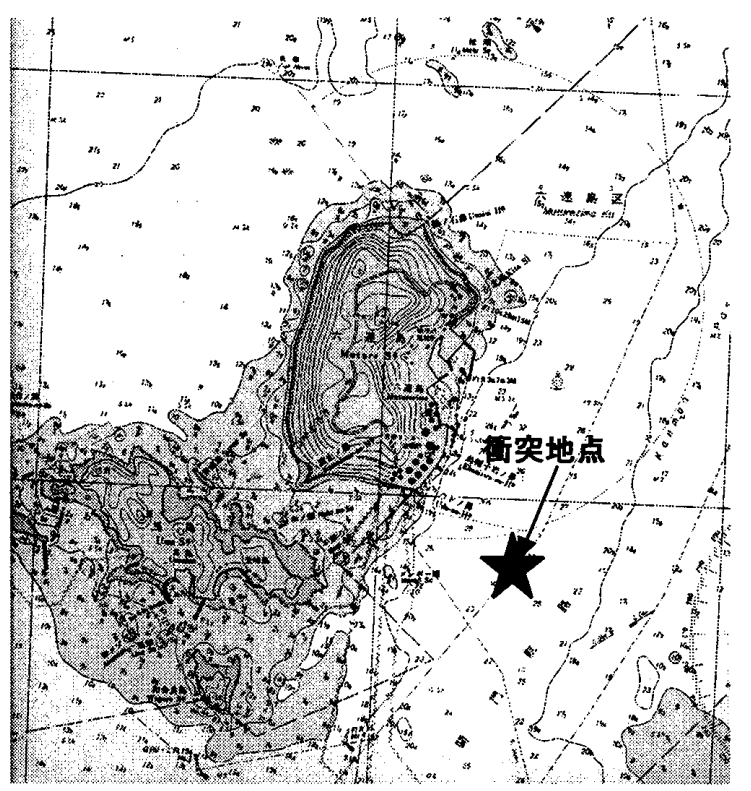

Fig.1 The collided position of Sekimaru 衝突場所は六連島灯台から約南 10 度東約 $1630 \mathrm{~m}$ の地点である。

\section{2 両船の運杭模様の要的}

関丸は定期検查を兼ねて舵その他の付属施設を修 理のため林兼造船株式会社 (以下「造船所」と略す)に
入渠中、 8 時 30 分頃、浜崎指定海難関係人が操船を 指揮し、後藤受審人立会の下で六連島南東沖合で舵 修理不十分といえる状態で試運転を施行した。その 後、主機 L0 ポンプが故障したので、それを修復後 14 時 30 分頃から再び旋回圈試験を実施した。関丸 は満珠丸を避けるため激右転全速後進とした。満珠 丸はそれまで関丸には注意を払っていなかったが、 関丸が後進と同時に満珠丸も全速後進としたが奏効 しなかった。関丸は午後 3 時 42 分頃左回頭しつつ満 珠丸に激しく衝突した。満珠丸船長は行方不明、甲 板員 1 名と機関員 1 名の計 2 名は死亡している。

\section{3. 海踓寒判庁の裁決}

\section{1 門司地方海難賽判庁の裁決（昭和 25 年 7 月 10 日言渡)}

主文 本件衝突は、指定海難関係人浜崎長太郎の 業務上の過失と、受審人後藤五郎の運航に関する職 務上の過失とに基因して発生したものであるが、満 珠丸船長沢井善之丞の運航に関する職務上の過失も またその一因をなすものである。

後藤五郎を戒告する。

\section{2 高等海難審判庁の裁決（昭和 26 年 9 月 27 日言渡)}

主文 本件衝突は、林兼造船株式会社の業務上の 過失によって発生したものである。

両審判庁の裁決の一覧を表 1 に示す。

\section{3 高等海蜼賽判庁の裁決で造船所が被った 不利益とは}

関丸事件の最高裁判決では、「海難の原因解明は事 実確認行為である」としている。しかし、「過失」の 認定は、名誉権と営業権が侵害される。これらの侵 害からの回復を行なうことは、法的保護に值する。

高審の審理過程は、当事者主義に違反し、不告不 理の原則にも違反している。又高審は、裁決後は自 らの取消は不可能である。海難審判法（以下「法」と略 す)にもその旨の取り消しを認めた規定は存在しな い。従って、法 53 条の救済によらざるを得ない。衝 突による被害者の損害賠償訴訟で、高審の過失の認 定は造船所にとって不利益を蒙った。

\section{4 東京高等裁判所の判決（昭和 27 年 12 月}




\section{6 日言渡）}

主文 高等海難審判庁が昭和 26 年 9 月 27 日にな した「本件衝突は林兼造船株式会社の業務上の過失
によって発生したものである」旨の裁決を取消す。訴 訟費用は被告の負担とする。

Table 1 The decision of Marine Accidents Inquiry Agency

\begin{tabular}{|c|l|l|}
\hline & \multicolumn{1}{|c|}{ 門司地方海難審判庁 } & \multicolumn{1}{|c|}{ 高等海難審判庁 } \\
\hline 受審人（船長） & 職務上の過失 戒告 & 過失なし \\
\hline $\begin{array}{c}\text { 指定海難関係人 } \\
\text { ドックマスター }\end{array}$ & 業務上の過失 勧告なし & 過失なし \\
\hline $\begin{array}{c}\text { 指定海難関係人 } \\
\text { 林兼造船所 }\end{array}$ & 指定されず & $\begin{array}{l}\text { 指定されず } \\
\text { 業務上の過失 勧告なし }\end{array}$ \\
\hline 主文 & $\begin{array}{l}\text { ドックスタタ-の業務上の過失と、船長の } \\
\text { 運行に関する職務上の過失とに基 } \\
\text { 因して発生した。兼造船所の業務上の過失によ } \\
\text { って発生した。 }\end{array}$ \\
\hline
\end{tabular}

Table 2 The Judgement of the Court

\begin{tabular}{|c|c|c|}
\hline & 東京高等裁判所 & 最高裁判所 \\
\hline 判決 & $\begin{array}{c}\text { 昭和 } 26 \text { 年 } 9 \text { 月 } 27 \text { 日になした } \\
\text { 「本件衝突は林兼造船株式会社の業 } \\
\text { 務上の過失によって発生したものであ } \\
\text { る」旨の裁決を取り消す。 } \\
\text { 訴訟費用は被告の負担とする。 }\end{array}$ & $\begin{array}{l}\text { 原判決を破棄する。 } \\
\text { 被上告人の訴えを却下 } \\
\text { する。 } \\
\text { 訴訟の総費用は被上告 } \\
\text { 人の負担とする。 }\end{array}$ \\
\hline $\begin{array}{l}\text { 高等海難審判庁の } \\
\text { 判断に対し }\end{array}$ & 否定 & 支持 \\
\hline 林兼造船所に対し & 過失なし 責任なし & 過失あり、責任あり \\
\hline
\end{tabular}

\section{5 最高裁判所の判決（最判昭和 36 年 3 月 15}

\section{日民集 15 巻 3 号 467 頁)}

主文 原判決を破萧する。被上告人の訴えを却下 する。訴訟の総費用は被上告人の負担とする。 両裁判所の裁決の一覧を表 2 に示す。

\section{4. 同㭗蒠例}

昭和 23 年から現在(平成 18 年 5 月 18 日)までの最 高裁判所上告事件 27 件、他審理中 1 件があり、その 一覧を表 3 に示す。

\section{5. 抗告诉公に付いて}

抗告訴訟とは、行政行為その他行政庁の公権力の 行使に関わる行為又は不行為により権利利益を侵害 された者が、その行為・不行為の適否を争う訴訟で ある(行訴法 3 条 1 項)。

行政事件訴訟の中核をなす訴訟形式である(原田 尚彦著、行政法要論全訂第二版 pp. 310～323)。

\section{6. 東京高等裁判所が処分性を忍めた理由}

処分性を認めた理由は次の二点に大別できる。 第一点、不告不理の原則及び審級制の原則に違反 
Table 3 Same instance as Sekimaru

\begin{tabular}{|c|c|c|}
\hline No & 事件名 & 最高裁判決年月日 \\
\hline 1 & 汽船石狩丸・機附帆船大德丸衝突事件 & 昭和 26 年 7 月 3 日 \\
\hline 2 & 汽船宗像丸・漁船日の出丸衝突事件 & 昭和 32 年 2 月 21 日 \\
\hline 3 & “汽船第六関丸・汽船満珠丸衝突事件 & 昭和 36 年 3 月 15 日 \\
\hline 4 & 汽船洞爺丸遭難事件 & 昭和 36 年 4 月 20 日 \\
\hline 5 & 汽船カルテックスダーバン・汽船アトランタ衝突事件 & 昭和 36 年 4 月 28 日 \\
\hline 6 & 汽船金剛丸・機附帆船三光丸衝突事件 & 昭和 43 年 2 月 27 日 \\
\hline 7 & 機船文丸・汽船第二拓南丸衝突事件 & 昭和 38 年 6 月 7 日 \\
\hline 8 & 汽船十勝丸・汽船日高丸・汽船北見丸遭難事件(併合審理事件) & 昭和 36 年 4 月 20 日 \\
\hline 9 & 機船りっちもんど丸・機船ときわ丸衝突事件 & 昭和 47 年 4 月 21 日 \\
\hline 10 & 機船第五隆邦丸傷害事件 & 昭和 44 年 4 月 24 日 \\
\hline 11 & 機船第一宗像丸・機船タラルドブロビーグ衝突事件 & 昭和 42 年 11 月 30 日 \\
\hline 12 & 機船日尚丸・機船豊国丸衝突事件 & 昭和 55 年 12 月 9 日 \\
\hline 13 & *機船はまなす丸・漁舟第三大勝丸衝突事件 & 昭和 53 年 3 月 10 日 \\
\hline 14 & 機船第十五砂畑丸・機船第十五万谷丸被引台船衝突事件 & 昭和 53 年 4 月 7 日 \\
\hline 15 & 機船第三松山丸・機船第六十五恵比須丸衝突事件 & 昭和 56 年 6 月 25 日 \\
\hline 16 & 機船山福丸・機船楽穂丸衝突事件 & 昭和 56 年 6 月 25 日 \\
\hline 17 & 機船菊光丸・機船日興丸衝突事件 & 昭和 59 年 9 月 20 日 \\
\hline 18 & *機船第三秀栄丸転覆事件 & 昭和 58 年 7 月 15 日 \\
\hline 19 & 機船第八金生丸・機船第三青運丸衝突事件 & 昭和 61 年 12 月 19 日 \\
\hline 20 & 油送船第三ごおるでんらっくす・油送船第十一霧島丸衝突事件 & 昭和 62 年 9 月 10 日 \\
\hline 21 & 交通船はりま・プレジャーボートサンテラス衝突事件 & 平成 4 年 4 月 23 日 \\
\hline 22 & *ケミカルタンカー第六明和丸爆発事件 & 平成 4 年 7 月 14 日 \\
\hline 23 & 貨物船ブレーメンセネター・栈橋衝突事件 & 平成 11 年 4 月 16 日 \\
\hline 24 & 漁船第二十五五郎竹丸転覆事件 & 平成 10 年 9 月 10 日 \\
\hline 25 & 貨物船新栄丸・貨物船アカデミックセミノフ衝突事件 & 平成 13 年 10 月 26 日 \\
\hline 26 & 油送船大港丸・遊漁船第十八大吉丸衝突事件 & 平成 15 年 1 月 25 日 \\
\hline 27 & 漁船第八瀧潮丸遊泳者死亡事件 & 平成 18 年 5 月 15 日 \\
\hline
\end{tabular}

注 1 ）以上は最高裁が関丸事件と同様に抗告訴訟を認めなかった事件であるが、その種類は、原因 解明裁決、勧告裁決及び過失だけが言渡された裁決等である。

（資料は高審の総務課からの照会による。）

注 2 ) 現在・プレジャーボートビクトリア正乗揚事件・平成 18 年 4 月 13 日上告継続中

注 3 ）指定海難関係人に関する事例（*印にて表示）は 4 件ある。

している。

第二点、高審の裁決の結果、造船所は名誉権、営 業権の侵害を蒙り、その何れも法的に保護されるべ き損害が発生している。

第一点に付いて 高審での審判の範囲は事件、受 受審人、指定海難関係人の全部に及ぶが、それ以外
の者には絶対に及ばない(法施行規則 63 条)。従って、 本件では造船所を審判の対象とはなし得ないのであ る。

第二点に付いて、東京高裁は、高審は衝突の原因 を一方的に判断して造船所の業務上の過失と認めて 
いる(呼び出し、口頭弁論、証拠提出等を認めていな い)。そして裁決の結果、名誉権、営業権の侵害を受 けていると判断して、造船所の訴えを認めている （法 38 条、39 条、40 条、40 条の $3 、 40$ 条の 4)。

\section{7. 取高裁が処分性を否定した理由（多数 説)}

本件は原因解明裁決であり造船所は事実上の不利 益を被るだけである。それは法律上の不利益ではな く、権利を制限し義務を課するものではない。造船 所に過失を確定する効力はない。従って、これを行 政処分と解し得ないので出訴することはできないの である。

不告不理に反することは首肯しうるのであるが、 これを以って裁決を取り消すことはできない。

尚、高審が自ら裁決の取消はできない、そのこと を以って事実確認行為は左右されないのである。 又裁決は証拠資料の価値しかないと解している。

著者等は最高裁の多数説は原因解明裁決を事実確 認行為と判断しており、事案に対して厳格に適用し ているものと考える。

\section{8. 最高裁の少数説}

勧告裁決は、準司法手続きによる裁決であり法律 上の義務を課しているので、行訴法上の処分に該当 する (法 63 条)、本件造船所は指定海難関係人ではな いが、高審が業務上の過失を認めていることから実 質的には勧告裁決と異ならない。

海難審判は技術的、専門的な方面から行なわれ正 確な事実認定が期待し得る。従って、民事、刑事の 裁判で裁決を尊重することはあり得るとしている。 しかし、私は刑事裁判では裁決の証拠を尊重するこ とは原則としてあり得ないと考える(犯罪とは構成 要件に該当し違法且つ有責な行為であることが要件 であることから、これらは総て改めて審理をする必 要がある)。この点は、成田頼明 (横浜国立大学教授) 先生も同旨である(自治研究 30 巻 11 号、p．65)。

法律用件事実であっても権利義務に影響を及ぼす 限り、法律的判断の争いは抗告訴訟の対象となる。 尚高審の本件裁決は営業権、名誉権を客観的に侵害 しているので法 53 条の訴えが許されるべきである。 又法施行規則 32 条からは本件のような裁決はで きないし、法 53 条 4 項は指定海難関係人に第二審請
求を認めていないが、これを以って抗告訴訟を認め ない趣旨であるとはいえないと判断している。

\section{9. 同機の目例に対する学説の見解}

\section{1 機船はまなす丸・漁舟第三大睠丸衙突事} 件

本件衝突事件で東京高裁は原因解明裁決でも受審 人に実際上の不利益があれば、第二審申立の利益は 存するとしているが、最高裁は関丸事件と同様にこ れを認めていない。大塚裁判官が反対意見で第二審 申立の利益の存することを認めている。

本件は地方審の原因解明裁決を不服として行なっ た高審への二審請求の適否が争われた点で、関丸事 件とは事例が異なるが二審請求を行なうについて 「法律上の利益」が認められるかを問題にし、消極の 結論をとる場合に原因解明裁決に対する取消訴訟の 訴えの利益にも共通している。その意味でも関丸事 件と思考過程を同様にしている。

浜川 清 (法政大学教授)先生は、本件（はまなす事 件)判例の批評の過程で、「最近の学説は訴えの利益 之行政処分性の何れにおいても原因解明裁決は取消 訴訟の対象となりうるとし、原因解明裁決、勧告裁 決に対して利害関係者は直接出訴が認められて良い と解する。直接出訴の意味は法第 53 条によるのでは なく、行訴法第 3 条、第 9 条に基づくものである。

最高裁は古典的な狭险な利益論を維持し、利害関 係者の司法的救済を閉ざしている嫌いがある。又海 難審判制度の円滑な運営を阻害する㲊もある論理、 結論の何れも支持し難いのである」と論じておられ $ろ^{(1)(2)}$ 。

\section{2 機船りっちもんど丸・機船ときわ丸街突 事件}

原茂太一(青山学院大学教授) 先生は、りっちもん ど丸事件判決に付いて、「我が国では特定なものを受 審人、指定海難関係人とし懲戒、勧告を前提として 手続きが進められるので過失の有無が前面に出てく ることは歪めない。これは裁決の主文にも明白に示 される。

この特質から過失の認定のみで懲戒を伴わない場 合であっても、そのものに対して怠慢、信頼度の欠 如、技量未熟など人格的、倫理的評価を生むことに なることは否定できない。 
裁決の結果がそのものに対し人格上、財産上重大 な損害を与える点では懲戒であろうと、勧告であろ うと、単なる過失の認定であろうと同様であり、裁 決を受けたものは等しく保護に值する利益を持つと いえるのではないかと考える」と論じておられる(3)。 この括弧内は法 53 条の抗告訴訟を認める見解であ ると解される。

\section{0. 绐第六勾丸の原因解明臷決に対す る当立者泝讼（行泝法第 4 条）に付いて}

徳本広孝 (明治学院大学教授) 先生は、「処分生之訴 えの利益を厳密に区別した上で、非処分性を維持し つつ当事者訴訟の活用を示唆する見解が存在してい た (9.1 参照 $)^{(2)}$ 。又新行政事件訴訟法は当事者訴訟 の規定の中で「公法上の法律関係に関する確認の訴 え」(行訴法 4 条)が明文化され、当事者訴訟 (特に確 認訴訟)の活性化が図られた。処分性が否定された事 案をこの確認訴訟で争うことを想定する改正法の下 では、原因解明裁決、勧告裁決の違法・無効の確認 を求めることが考えられる ${ }^{(3)}$ 。しかし、最高裁及び 東京高裁は法 46 条 1 項の「理事官又は受審人」を限 定列挙と解するので結果的には指定海難関係人は当 事者訴訟を提起する機会は失われることになる。

従って、海難審判と行政訴訟の関係を改めて整序す る必要があるといえる。又原因解明裁決・勧告裁決 に付いての第 2 審請求は処分に対する不服申立では なく、特別の不服申立ということになる」と論じて おられる(4)。

\section{1. 私見}

関丸事件で東京高裁の判決、最高裁の少数説、及 び本件に付いて抗告訴訟 (法 53 条)を認める説 (学説 としては多数説)が正当であると考える。りっちもん ど丸事件で最高裁の海難審判に対する抗告訴訟は確 定したとする学説もあるが、従来の行訴法の研究論 文を読む限りそのように断定することはできないと 思われる。

学説判例共に懲戒裁決は行政処分と認めて法 53 条の抗告訴訟を認めることに異論はないと思われる。 勧告裁決、単に過失を言渡された原因解明裁決、戒 告裁決は少なくとも「制裁の効果」があると考える。 しかもそれらの裁決を受けたものは、客観的には名 誉権、営業権等の被害を受けることになる。勧告裁
決、原因解明裁決は事実上の損害であり、事実上の 被害であるから、それらの裁決を受けたものにとつ て「我慢」を強いることは基本的人権の保障(憲法 13 条、29 条、31 条、76 条 2 項)の見地から許されない。 従って、抗告訴訟が認められるべきである。これを 当事者訴訟 (行訴法第 4 条) で理論的に解決する説 (9.1 浜川説)もあるが、それは今後の研究課題でも ある。

行訴法第 9 条 2 項の新設の趣旨は、国民の権利利 益の救済範囲の拡大を図ることにあり、その為、取 消訴訟の原告適格に附いて適切な判断が担保される ようにすることである。

本条項が直ちに海難審判において原因解明、勧告 の裁決に適用されることはないと思われるが、本条 項の趣旨は援用されるべきであると考える。

\section{2. おわりに}

最高裁は裁決書を「鑑定書」乃至「処方箋」と評価し ているが、これを本来の「裁決書」と評価されるよう に努力すべきであると考える。

当時の最高裁調查官の田中真次裁判官は、「林兼造 船所事件で大法廷判決の少数意見は、多数意見に比 ベて高次元の立場から本件を考察しているように思 われる。」と論述されている。現在も法律上保護され る必要性のある勧告裁決を受けたものから、法 53 条により訴えが裁判所に提起されていることを考察 すると、海難審判を行うに際して勧告裁決をなす場 合には、勧告を受けたものが社会的不利益を被るこ とが在る場合を勘案し、より一層基本的人権 (憲法 13 条、 29 条、32 条 76 条)を尊重し、適正手続きの 保障、当事者主義を遵守し、抗告訴訟に至らないよ う努めるべきであると思慮する。裁判所に対しても、 海難審判庁の裁決に対する抗告訴訟を原則として、 積極的に受理すべきではないかと考える。又、最高 裁判所裁判官からは判決を通して指摘があるが、又 学者からは種々の論文や参考書等で多数の指摘があ るように、海難審判法が本来の法律の体裁を整える よう次の項目に付いて改正すべきであると考える。

1、審判法 46 条 1 項 地方審で裁決を受けたもの が不服ある場合いは、何人も高審へ第二審請求をな しうる。

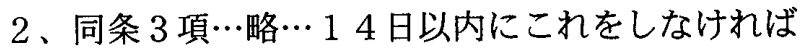
ならない。 
3、審判法 53 条 1 項 高審で裁決を受けたものが 不服ある場合は、何人も東京高裁に訴えを提起でき る。

4、審判法 53 条の $2 、 1$ 項 高審が認定した事実 は、実質的証拠があるときには、裁判所を拘束する。

同条 2 項、前項の実質的な証拠の有無は、裁判所 がこれを判断する。

上記した 4 項目は、総て立法論としての改正指針 であるが、これを以ってすれば最高裁は、原則とし てどのような態様乃至内容の抗告訴訟であっても、 㶳却することはできないと考える。

\section{参考文献}

（1）判例時報 №.909

(2) 判例評論 $\mathrm{N} 0.240$

（3）ジュリストNo.508、pp. 91〜95

（4）塩野宏著、行政法 II 第 4 版、2005、P. 238

（5）行政判例百選 II 第 5 版No. 182、pp. 338～339

(6) 海難審判裁決録 (昭和 25 年 7 月分) 海難審判協会 発行、高等海難審判庁監修

(7) 海難審判裁決録 (昭和 26 年 9 月分) 海難審判協会 発行、高等海難審判庁監修

（8）東京高等裁判所、昭和 27 年 12 月 16 日判決、事 件番号, 昭和 27 年行ナ 26

(9) 最判昭和 36 年 3 月 15 日、民集 15 巻 3 号 P. 467

(10) 自治研究、 30 巻 11 号、P. 65

(11)ジュリストNo.225 pp. 26〜30、1961

(12)ジュリスト№.240

（13）ジュリスト増刊、改正行政事件訴訟法研究、2005

（14）ジュリストNo.1310、特集行政訴訟判例の展開、 2006

（15）小早川光郎: 行政法 (上)、弘文堂、1999

(16) 原田尚彦:行政法要論、学陽書房、1989

（17）竹田 稔監修:海難審判之行政訴訟、判例時報社、 1994

（18）田口守一:刑事訴訟法、弘文堂、pp. 457 465、 2005

（19）松本博之、上野泰男共著、民事訴訟法、弘文堂、 pp. $678 \sim 687$

(20)森 清:海難審判制度の研究、中央大学出版部、 pp. $441 \sim 458$

(21) 橋本公亘: 日本国憲法、有斐閣、昭和 63 年、 pp. $120 \sim 155 、$ pp. $343 \sim 347$ （22）芦部信喜:憲法、岩波書店、1997、pp. 78～209

（23）浦部法穂: 憲法学教室、日本評論社、pp. 65～270 